\title{
A new treatment using low level laser therapy for dehiscence saphenectomy post myocardial revascularization in diabetic patients
}

\author{
NC Pinto ${ }^{1 *}$, PMA Pomerantzeff ${ }^{1}$, MHC Pereira ${ }^{2}$, F Jatene $^{1}$, MC Chavantes $^{1}$ \\ From 23rd World Congress of the World Society of Cardio-Thoracic Surgeons \\ Split, Croatia. 12-15 September 2013
}

\section{Background}

In Brazil, the main cause of death is the coronary heart disease and the surgical treatment used is the Myocardial Revascularization (MR). Patients undergoing to MR through bypass saphenous vein have been developed dehiscence in $10 \%$. Dehiscence of surgical incision through Bioestimulation treatment with Low Level Laser in patients that underwent to MR seems to be an unprecedented new treatment and less invasive technique in the medical armamentarium.

\section{Methods}

It was analyzed 10 diabetic patients, mean age 65,3 years that after surgery of MR evaluated for dehiscence surgical saphenectomy in lower member as well as edema and pain. Diode Laser C.W. (685 nm wavelength) with Power= $25 \mathrm{~mW}$, Time $=30 \mathrm{~s}$, Fluency $=4 \mathrm{~J} / \mathrm{cm} 2$ was applied, punctually surrounding surgical wound's sore every $2 \mathrm{~cm}$.

\section{Results}

It revealed early reduction of the pain, as well as improved the health appearance of granulated tissue, decrease inflammatory process, wound's size and reduction fibrin since the very first application. In superficial wounds only 3 sessions was required, while in the extensive wounds 8-10 applications was necessary.

\section{Conclusion}

LLLT were effective in tissue repair, closing the saphenectomy dehiscence with a substantial improvement of

\footnotetext{
* Correspondence: nathalicordeiro@hotmail.com

'Cardiovascular Surgery Department, Heart Institute (InCor), Hospital das Clínicas da Faculdade de Medicina da Universidade de São Paulo, São Paulo, Brazil

Full list of author information is available at the end of the article
}

patient's quality of life, that benefits patients and Institutions, with cost-effectiveness, beyond denoted to be a less invasive treatment.

\section{Authors' details}

'Cardiovascular Surgery Department, Heart Institute (InCor), Hospital das Clínicas da Faculdade de Medicina da Universidade de São Paulo, São Paulo, Brazil. ${ }^{2}$ Anesthesiology Department, Heart Institute (InCor), Hospital das Clínicas da Faculdade de Medicina da Universidade de São Paulo, São Paulo, Brazil.

Published: 11 September 2013

\section{doi:10.1186/1749-8090-8-S1-0121}

Cite this article as: Pinto et al:: A new treatment using low level laser therapy for dehiscence saphenectomy post myocardial revascularization in diabetic patients. Journal of Cardiothoracic Surgery 2013 8(Suppl 1): O121.
Submit your next manuscript to BioMed Central and take full advantage of:

- Convenient online submission

- Thorough peer review

- No space constraints or color figure charges

- Immediate publication on acceptance

- Inclusion in PubMed, CAS, Scopus and Google Scholar

- Research which is freely available for redistribution
C Biomed Central

\section{() BioMed Central}

(c) 2013 Pinto et al; licensee BioMed Central Ltd. This is an Open Access article distributed under the terms of the Creative Commons Attribution License (http://creativecommons.org/licenses/by/2.0), which permits unrestricted use, distribution, and reproduction in any medium, provided the original work is properly cited. 